\title{
EXTRACTION AND SCREENING OF PHENOLICS OF SOME SPODOPTERA LITTORALIS (BOISD.) HOST PLANTS
}

\author{
AMIN, T. R. ${ }^{1}$, S. ABO EL-ENIN ${ }^{2}$ and TAKWA H. ELLAKWA ${ }^{1}$ \\ 1. Plant Protection Research Institute, ARC, Dokki, Giza, Egypt \\ 2. Dept. Of Chemistry, Faculty of Science, Ain-Shams University, Egypt
}

(Manuscript received 10 July 2014)

\begin{abstract}
Total phenols of some cotton leafworm, Spodoptera littoralis (Boisd.) host plant leaves were extracted by using homogenizing method and aqueous $(80 \%, \mathrm{v} / \mathrm{v})$ methanol and acetone. Quantification of phenolics was carried out by FolinCiocalteau method. The results revealed that the amount of phenols significantly differed among the tested host plants in the following order: Castor bean < garden rocket < cabbage < grapevine. The total phenols of cabbage and castor bean leaves extracted by methanol were significantly higher than those extracted by acetone. They were 5.83 and $4.63 \mathrm{mg} \mathrm{GA} / \mathrm{dw}$ for cabbage and castor bean leaves extracted by methanol, respectively, while they equaled to 5.2 and $4.03 \mathrm{mg} \mathrm{GA} / \mathrm{dw}$ for those extracted by acetone, respectively. On the other hand, the results revealed that the amount of phenolics was not proportional to the amount of crude extract produced. It could be concluded that aqueous methanol is more efficient than aqueous acetone in extracting phenolics from the tested host plants of the cotton leafworm, and by using homogenizing methods, the yield of phenols was satisfactory and rapidly extracted. The situation that fulfils the requirement of more screening of these compounds in different $S$. littoralis host plants, since current strategies to control insects using natural pesticides and transgenic plants might rely on phenolic compounds that confer resistance to field crops.
\end{abstract}

\section{INTRODUCTION}

Phenolics are among the most widely studied plant secondary compounds, being formed in the leaves of all terrestrial higher plants (Riipi et al., 2002). Phenolic compounds include phenolic acids, polyphenols, flavonoids and tannins. They are considered as important components of both constitutive and induced defense against herbivores and pathogens, by acting as antinutritive compounds affecting the growth and development of a variety of insects (Reese and Beck, 1976, Felton et al., 1989, Appel, 1993, Abdel-Baky et al., 2005).

Phenolic compounds have been quantified in several plant species (e.g. Kähkönen et al., 1999), and identified (e.g. Nakatani, 1997, Abd El-Ghany, 2006). In attempts to control insects using natural compounds, effects of crude plant extracts 
contained phenolic compounds have been examined (e.g. Hegazy et al., 1992, Heil et al., 2002, Gaaboub et al., 2005).

In spite of, the cotton leafworm, Spodoptera littoralis (Boisd.) is a polyphagous pest, the phenolic content of its most host plants is not known. Antonious et al. (1999) measured total phenols of different commercial tomatoes leaflets cultivars in relation to mortality and feeding of fourth-instar larvae of $S$. littorals.

The present study was performed to (1) Screen some $S$. littoralis host plants as natural sources of phenolics. (2) Compare between different solvents by using homogenizing method with respect to their efficiency in extracting phenolic compounds as crude extracts.

\section{MATERIALS AND METHODS}

\section{- Host plants:}

Four different host plants were selected (Table, 1) to detect their phenolic content. They are among 73 plant species known to be attacked by the cotton leafworm, S. littoralis larvae in Egypt. Fresh plant leaves were collected from Menoufia province cultivars, and were used directly for phenol extraction.

\section{- Extracts:}

Ten plant leaves from each replicate (4-6 replicates for each host plant species) were washed with $\Delta \mathrm{H}_{2} \mathrm{O}$ and placed in an oven to dry at $45^{\circ} \mathrm{C}$ for 7 days. Then they were grounded in an electric grinder into fine powder. Extraction was performed as described by Kähkönen et al. (1999) using the homogenizing method of extraction. Grounded plant leaves $(5 \mathrm{gm})$ were extracted with $2 \times 10 \mathrm{ml}$ of $80 \%$ aqueous methanol using electric homogenize for $5 \mathrm{~min}$. Samples were centrifuged (10 min, $3000 \mathrm{rpm}$ ), and the combined extracts were poured into pre-weighed small conical flasks. Methanol was removed under reduced pressure. The solid residue (crude extract) was weighed and dissolved in $\Delta \mathrm{H}_{2} \mathrm{O}$ to a $5 \mathrm{ml}$ volume.

Extraction was done also by another solvent, acetone. Plant leaves ( $5 \mathrm{gm}$ ) was extracted with $3 \times 25 \mathrm{ml}$ of $70 \%$ aqueous acetone using magnetic stirrer for 45,45 and $20 \mathrm{~min}$. Extraction was continued as described in methanol extraction.

Table 1. Plant species used as sources for phenolics.

\begin{tabular}{|c|c|}
\hline Common name & Scientific name \\
\hline Cabbage & Brassica oleracea \\
\hline Castor bean & Ricinus communis \\
\hline Grapevine & Vitis vinifera \\
\hline Garden rocket & Eruca sativa \\
\hline
\end{tabular}

- $\quad$ Leaves were the plant part that used. 


\section{- Determination of total phenolics:}

The amount of phenols extracted was determined by Folin-Ciocalteu method as modified by Singlton and Rossi (1965). Gallic acid standard (5 gm\%) was used, and the total phenolic content was expressed as mg gallic acid per gm dry weight of the original sample ( $\mathrm{mg} \mathrm{GA} / \mathrm{gdw}$ ).

\section{RESULTS AND DISCUSSION}

\section{-Homogenizing extraction using aqueous solvents:}

The assays used for the analysis of phenolics can be classified as either those which determine total phenolic content, or those quantifying an individual phenolic or specific group or class of phenolic compounds. However, phenolic compounds must first be extracted from their source prior to any analysis.

The yield of total phenols extracted from the leaves of different plant species using aqueous solvents (80\%) is illustrated in Table (2). Methanol was more efficient than acetone in extracting phenols. Total phenols of cabbage and castor bean leaves that extracted by methanol were significantly increased than those extracted by acetone. They were 5.83 and $4.63 \mathrm{mg} \mathrm{GA} / \mathrm{dw}$ for cabbage and castor bean leaves extracted by methanol, respectively, while they equalled to 5.2 and $4.03 \mathrm{mg} \mathrm{GA} / \mathrm{dw}$ for those extracted by acetone, respectively. The extraction of garden rocket and grapevine leaves using methanol, also yield, increased amount of phenols than acetone extraction, but it was a non significant increase. The amount of total phenols increased in following order:

Castor bean $<$ garden rocket $<$ cabbage $<$ grapevine.

Table 2. Total phenols extracted by homogenizing method from different plant leaves.

\begin{tabular}{|c|c|c|}
\hline \multirow{2}{*}{ Extracted plant } & \multicolumn{2}{|c|}{ Total phenols (mgGA/gdw) } \\
\cline { 2 - 3 } & \multicolumn{2}{|c|}{ Extraction solvent } \\
\cline { 2 - 3 } & Methanol & Acetone \\
\hline Castor bean & $4.63 \pm 0.152^{\mathrm{a}}$ & $4.03 \pm 0.15^{\mathrm{b}}$ \\
\hline Cabbage & $5.83 \pm 0.2^{\mathrm{b}}$ & $5.2 \pm 0.26^{\mathrm{c}}$ \\
\hline Grapevine & $6.9 \pm 0.1^{\mathrm{c}}$ & $6.6 \pm 0.36^{\mathrm{a}}$ \\
\hline Garden rocket & $5.16 \pm 0.2^{\mathrm{a}}$ & $5.0 \pm 0.2^{\mathrm{cd}}$ \\
\hline
\end{tabular}

- Data are presented as the mean $\pm S D$

-Means, within a column, bearing different subscripts are significantly different $(P<0.05, A N O V A, L S D)$.

Means were separated by Duncan's multiple range test.

$-\mathrm{GA}=$ gallic acid, $\mathrm{DW}=$ dry weight of the original plant sample. 
Quantitative extraction of phenolic compounds is difficult, and chemical changes may occur during extraction. High temperature or extended extraction enabled by high temperature is possibly accomplished at the cost of the degradation of the more labile compounds (Ribérau-Gayon, 1972). Many phenolic compounds isomerise in sunlight (trans-cis conversion, Kahnt, 1967), react with oxygen (quinone formation) and with methanol at room temperature at pH 6 (Haslam, 1966). So a short extraction with homogenizer in an unheated solvent that performed during the present experiments, might be suitable. Refluxing and soxhelt methods were more efficient in phenol extraction than homogenizing methods, but when using pure solvents (Keinänen 1993).

Aqueous solvents are more efficient than pure ones, they proved to be effective in the extraction of phenolic compounds, especially from dried plant material (Harborne, 1984). The extractability of aqueous methanol was proved, as shown in Table (2), to be more efficient than aqueous acetone, this might be due to the fact that methanol is more polar. Solubility of phenolics is governed by the type of solvent (polarity) used, degree of polymerization of phenolics, as well as interaction of phenolics with other food constituents and formation of insoluble complexes (Naczk and Shahidi, 2004).

Kenänen (1993) tested the efficiency of commonly used methods (homogenizing, refluxing and soxhelt) and solvents (ethanol, methanol and acetone) for the extraction of flavonoids from dried birch leaves. He reported that water improved especially the efficiency of the weak solvent and pure acetone which was as good as aqueous alcohols in fluxing and homogenizing but was a less suitable solvent for soxhelt extraction. The present results also revealed that acetone is of good extraction efficiency, but methanol was more efficient in some cases.

\section{-Crude extract:}

The amount of dry crude extract (Fig. 1) differed according to the plant species and the solvent used. The crude extract of acetone extraction was 101.2, 64.3, 89.3 and $52.1 \mathrm{mg}$ for cabbage, garden rocket, castor bean ad grapevine, respectively, while the yield of methanol extraction was 72.6, 87.5, 110.3 and 84.6 $\mathrm{mg}$, respectively. It was observed that the amount of phenolics extracted was not proportional to the amount of crude extract that certainly contained other phytochemical substances such as alkaloids. Therefore, the amount of total phenols was related to the dry weight of the original plant sample.

It is obvious that the total phenolic content measured in the present study not give a full picture of the quality of the phenolic constituents in the extracts. However, the screening of phenolic content in plants is of a significant value. Heil et al. (2002) reported that content of phenolic compounds in leaf extracts often serve as a measure of plant anti-herbivore defense. 
It could be concluded that aqueous methanol is more efficient than aqueous acetone in extracting phenolics from the tested host plants of the cotton leafworm, and by using homogenizing method, the yield of phenols was satisfactory and rapidly extracted. The situation that fulfils the requirement of more screening of these compounds in different $S$.

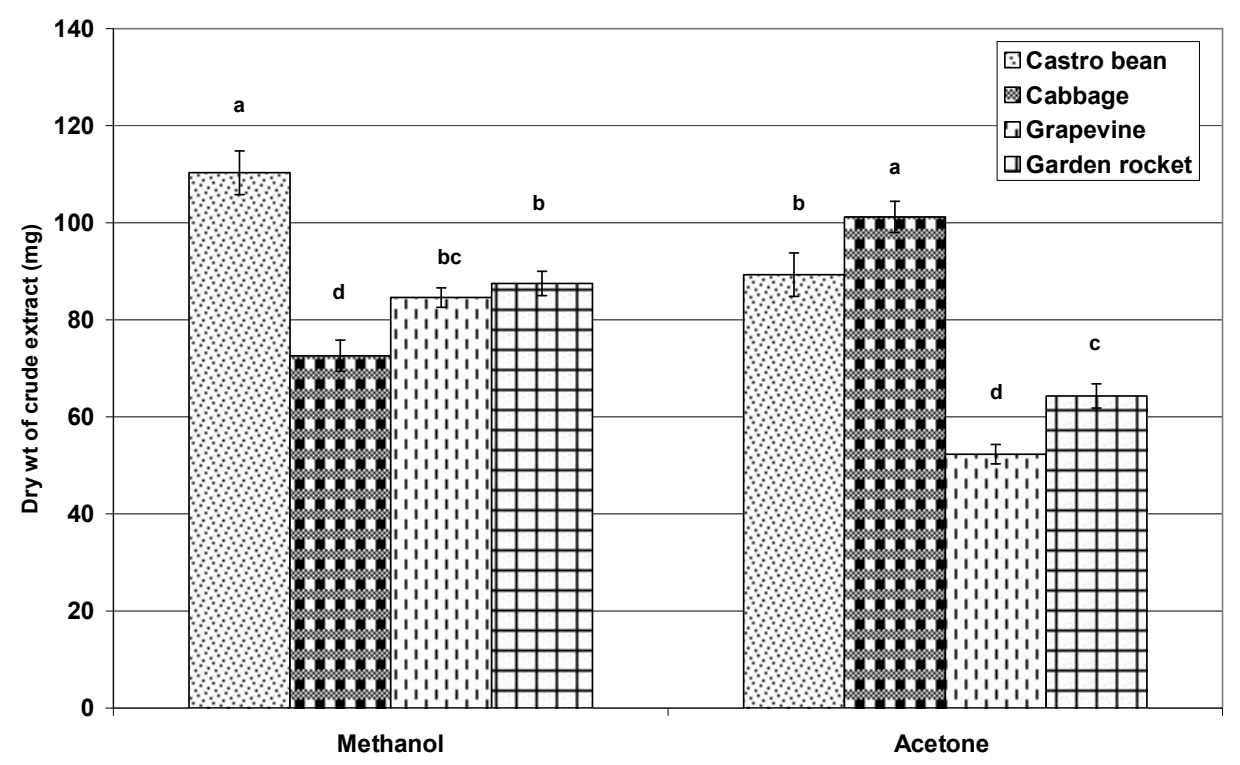

Fig. . $\quad$ Crude extract of different plant leaves.

- Data are presented as the mean \pm SD. Dry wt $=$ dry weight of the extract using homogenizing method. Means bearing different subscripts are significantly different $(P<0.05$, ANOVA, LSD, Duncan's multiple range test).

littoralis host plants, since current strategies to control insects using natural pesticides and transgenic plants might rely on phenolic compounds that confer resistance to field crops.

\section{REFERENCES}

1. Abd El-Ghany, A. M. 2006. Plant extracts as effective compounds in insect control. Ph. D. Thesis, Fac. Agric., Cairo Univ.

2. Abdel-Baky, N. F., A. M. Abou-Naga, M. E. El-Nagar and G. A. M. Heikal. 2005. Biochemical plant constituents affecting resistance to Bemisia argentifolii Bellows \& Perring (Hemiptera : Aleyrodidae) infestation in soybean and mung-bean leaves. Egypt J. Agric. Res., 83: 987-1005.

3. Antonious, G. F., J. C. Synder and D. L. Dahlman. 1999. Tomato cultivar susceptibility to Egyptian cotton leafworm (Lepidoptera: Noctuidae) and Colorado potato beetle (Coleoptera: Chrysomelidae). J. Entomol. Sci., 34: 171-182.

4. Appel, H. M. 1993. Phenolics in ecological interaction: the importance of oxidation. J. Chem. Ecol., 19: 1521-1552. 
5. Felton, G. W., K. Domato, R. J. Del Vecchio and S. S. Duffy. 1989. Activation of plant foliar oxidases by insect feeding reduces the nutritive quality of foliage for noctuid herbivores. J. Chem. Ecol., 15: 2667-2694.

6. Gaaboub, I., S. Halawaa, A. F. El-Aswad and E. N. Khamis. 2005. Feeding deterrent and growth inhibitory properties of Neotorularia aculeolata against the cotton leafworm, Spodoptera littoralis (Boisd.). Egypt, J. Agric. Res., 83: 973-986.

7. Harborne, J. B. 1984. Phytochemical methods, Chapman and Hall: London.

8. Haslam, E. 1966. Chemistry of vegetable tannins. Academic Press, London and New York.

9. Hegazy, G., A. G. Antonious, M. F. Shaarawy and A. L. Youssef. 1992. Reaction of feeding the cotton leafworm, Spodoptera littoralis (Boisd.) on certain plant leaves. 2 : Effect of plant extracts. Mededelingen-Van-de-Facultite. Landbou wwetens- chappen Rijksuniverseit Gent, 57: 697-705.

10. Heil, M., B. Baumann, C. Andary, K. E. Linsenmair and D. Mckey. 2002. Extraction and quantification of "condensed tannins" as a measure of plant anti-herbivore defence? Revisting and old problem. Naturwissenschaften, 89: 519-524.

11. Kähkönen, M. P., A. I. Hopia, H. J. Vuorela, J. P. Rauha, K. Pihlaja, T. S. Kujala and M. Heinonen. 1999. Antioxidant activity of plant extracts containing phenolic compounds. J. Agric. Food Chem., 47: 3954-3962.

12. Kahnt, G. 1967. Trans-C is equilibrium of hydroxyl cinnamic acids during irradiation of aqueous solution at different pH. Phytochem., 6: 755-758.

13. Keinäen, M. 1993. Comparison of methods for the extraction of flavonoids from birch leaves (Betula pendula Roth.) carried out using high-performance liquid chromatography. J. Agric. Food Chem., 41: 1986-1990.

14. Naczk, M. and F. Shahidi. 2004. Extraction and analysis of phenolics in food. J. Chromatography A, 1054: 95-111.

15. Nakatani, N. 1997. Antioxidants from species and herbs. In Natural antioxidants: Chemistry, Health effect and Applications, Shahidi, F. Ed., AOCS Press: Champaign, IL, 1997, Pp64-75.

16. Rees, J. C. and S. D. Beck. 1976. Effects of allelochemics on the black cutworm, Agrotis ipsilon, effects of benozquinone, hydroquinone and duroquinone on larval growth, development and utilization of food. Ann. Entomol. Soc. Am., 69: 59-67.

17. Ribérau-Gayon, P. 1972. Plant phenolics, Oliver \& Boyd: Edinburgh.

18. Riipi, M., V. Ossipov, K. Lempa, E. Haukioja, J. Koricheva, S. Ossipova and K. Pihlaja. 2002. Seasonal changes in brich leaf chemistry: are there trade-offs between leaf growth and accumulation of phenolics?. Oecdogia, 130: 380-390.

19. Singlton, V. L. and J. A. Rossi. 1965. Colorimetery of total phenolics with phosphomolybdic-phosphotungstic acid reagents. Am. J. Entomol. Vitic., 16: 144158. 


\section{إستخلاص وتقدير محتوي الفينولات لبعض النباتات التي تتظذي عليها دودة ورق القطن}

طارق رئيس أمين'، صلاح أبو العينين'، تقوي حامد اللقوة'

$$
\text { r r . معهد الكوثياء ، كلية العلوم ، جامعة النباتات ، مركز البحوث الزراعية ، الدقي - جيزة }
$$

تم إستخلاص الفينو لات الموجودة في بعض أور اق النباتات التي تتخــــي عليهــا دودة ورق القطن وذللك بإستخدام طريقة التجانس عن طريق المذيبات المائية منل الميثانول ــ\% و الأســيتون

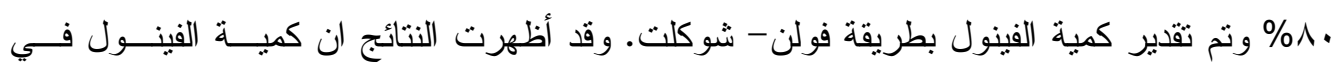

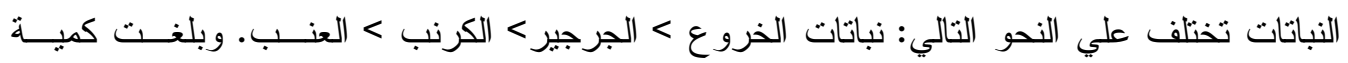

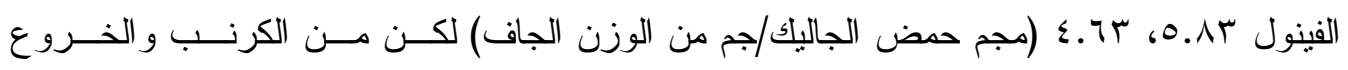

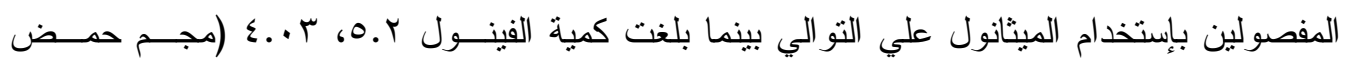

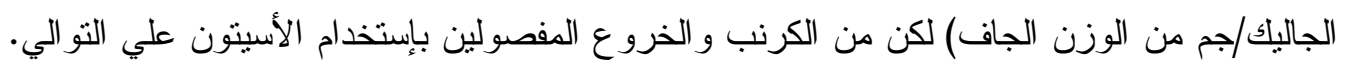

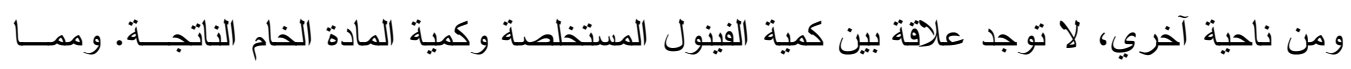
سبق نستتنج أن الميثانول أكثر فاعلية من الأسيتون في عملية فصل كمية الفينول من النباتات العائلــــة

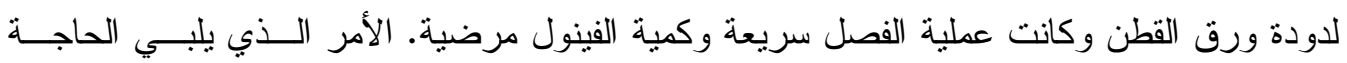

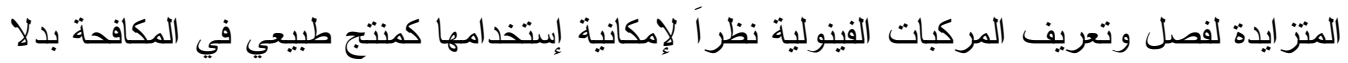
من المبيدات أو إستخدامها في مجال الهندسة الور اثية لتضفي نوع من الحماية علي المحاصيل. 